\title{
RANCANG BANGUN PURWARUPA APLIKASI KENDALI LAMPU RUMAH (SMART HOME) BERBASIS IoT DAN ANDROID YANG TERKONEKSI DENGAN FIREBASE
}

\author{
Adam Puspabhuana $^{1}$, P Yudi Dwi Arliyantoº \\ ${ }^{1}$ Program Studi Teknik Komputer / Politeknik Meta Industri Cikarang/ \\ adam.puspabhuana@politeknikmeta.ac.id \\ ${ }^{2}$ Program Studi Teknik Komputer / Politeknik Meta Industri Cikarang/ \\ yudi@politeknikmeta.ac.id
}

\begin{abstract}
The development of Android-based applications has grown rapidly over the past decade. In addition, robotics-based hardware technology connected to the Internet (IoT) has also developed. Smart home technology today is a technology that collaborates android applications with IoT devices. This IoT-based smart home technology controls home electronic devices based on commands given through the android application. Google is one company that has implemented smart home technology both with button commands and with the human voice.

This research was conducted to provide optional solutions such as Google's smart home technology to easily and quickly develop android applications that can control home electronic devices using IoT devices connected to the Internet. The home electronic device used for this research is an electric lamp. The android application editor used to develop applications is App Inventor. Block-based programming makes it easy for users to create android applications without having to have experience in programming. The IoT module used is using the nodeMCU device. This device communicates with wireless access point devices that are connected to the Internet. The test is done by pressing a button or voice command on the android application. This command will be converted in text form and sent to firebase. This text data is read by the program in the IoT device and sends a signal to the lamp to turn on or off.

The result of this research is a prototype that is simple, easy, fast and cheap both in implementation and development. This prototype makes it easier for someone to develop this smart home technology so that they can control home lights.
\end{abstract}

Keywords : Android, App Inventor, Smart Home, IoT, Firebase

\begin{abstract}
ABSTRAK
Perkembangan aplikasi berbasis android makin berkembang pesat selama satu dekade ini. Selain itu, berkembang pula teknologi perangkat keras berbasis robotika yang terhubung dengan Internet (IoT). Teknologi smart home saat ini adalah teknologi yang mengkolaborasikan aplikasi android dengan perangkat IoT. Teknologi smart home berbasis IoT ini mengendalikan perangkat elektronik rumah berdasarkan perintah yang diberikan melalui aplikasi android. Google merupakan salah satu perusahaan yang telah menerapkan teknologi smart home baik dengan perintah tombol maupun dengan suara manusia.

Penelitian ini dilakukan untuk memberikan solusi pilihan seperti teknologi smart home Google untuk mengembangkan aplikasi android dengan mudah dan cepat yang dapat mengendalikan perangkat elektronik rumah menggunakan perangkat IoT yang terhubung dengan Internet. Perangkat elektronik rumah yang digunakan untuk penelitian ini adalah lampu listrik. Editor aplikasi android yang digunakan untuk mengembangkan aplikasi adalah App Inventor. Dengan pemrograman berbasis blok memudahkan pengguna membuat aplikasi android tanpa harus memiliki pengalaman dalam pemrograman. Modul IoT yang digunakan adalah menggunakan perangkat nodeMCU. Perangkat ini berkomunikasi dengan perangkat wireless access point yang telah terhubung dengan Internet. Pada pengujian dilakukan dengan menekan tombol atau perintah suara pada aplikasi android. Perintah ini akan dikonversi dalam bentuk teks dan dikirimkan ke firebase. Data teks ini dibaca oleh program dalam perangkat IoT dan mengirimkan sinyal pada lampu untuk hidup (on) atau mati (off).
\end{abstract}


Hasil dari penelitian ini merupakan bentuk purwarupa yang sederhana, mudah, cepat dan murah baik dalam implementasi dan pengembangan. Dari purwarupa ini memudahkan seseorang untuk mengembangkan teknologi smart home ini sehingga dapat mengendalikan lampu rumah.

Kata Kunci : Android, App Inventor, Smart Home, IoT, Firebase

\section{PENDAHULUAN}

Teknologi internet mendorong berkembangnya aplikasi teknologi informasi baik yang berbasis website maupun android. Untuk mengembangkan aplikasi berbasis android pun dipermudah dengan hadirnya App Inventor. App Inventor dikembangkan oleh MIT (Massachusetts Insitute of Technology) pada tahun 2011 (Kincaid, 2011). Ini adalah aplikasi untuk mengembangkan aplikasi android yang berbasis website yang dapat diakses sescara online. Aplikasi ini menggunakan bahasa pemrograman berbasis blok. Pada penelitian ini menggunakan App Inventor untuk mengembangkan aplikasi android dan menggunakan salah satu fitur App Inventor yaitu Firebase yang merupakan basis data berbasis cloud.

Perkembangan internet juga mendorong berkembanganya teknologi IoT atau Internet of Things. Smart Home atau rumah pintar adalah salah satu teknologi yang memudahkan perangkat listrik di dalam rumah dapat berfungsi sesuai dengan kebutuhan secara otomatis. Contohnya lampu yang dapat hidup dan mati dengan otomatis menggunakan sensor cahaya. Dengan menggunakan teknologi IoT yang pastinya terhubung dengan koneksi Internet, pemilik rumah dapat mengatur dan mengendalikan perangkat listrik di rumahnya dari jauh. Salah satu modul (perangkat keras) yang terdapat fitur Wi-Fi didalamnya adalah NodeMCU. Modul ini dapat terhubung dengan koneksi nirkabel dan perangkat listrik. Salah satu perangkat listrik yang dijadikan bahan penelitian adalah lampu rumah. Peneliti membuat purwarupa sederhana berupa aplikasi android dengan perintah suara (speech recognition) dan juga tombol. Aplikasi ini terkoneksi dengan firebase untuk mengambil dan merubah data. Data yang dikirim atau diterima adalah status hidup (on) dan mati (off). Perangkat nodeMCU terhubung dengan firebase dalam mengambil data yang dikirim dari aplikasi android. Program yang telah disimpan dalam nodeMCU akan mengatur kondisi lampu untuk hidup (on) atau mati (off). Penelitian ini dilakukan sebagai solusi pilihan dari teknologi smart home yang dikembangkan oleh Google atau Amazon. Dengan purwarupa ini penghuni rumah dapat memiliki salah satu fitur yang sama seperti yang dimiliki oleh Google (Speech Recognition) atau Amazon (Alexa) yaitu mengendalikan perangkat listrik (lampu) dengan menggunakan perintah suara manusia yang dapat ditentukan sendiri oleh penggunanya.

\section{LANDASAN TEORI}

\subsection{App Inventor}

Pada tahun 2007, Google memulai proyek App Inventor yang diprakarsai oleh Prof. Hal Abelson dari MIT (Massachusetts Institute of Technology). Proyek ini terinspirasi oleh meningkatnya minat pada bahasa pemrograman berbasis blok seperti scratch. Pada saat ini pula android pertama dirilis. Pada tahun 2011, Google menutup proyek ini dan dimigrasikan ke MIT. Pengembangan teknik yang dilakukan oleh MIT berfokus pada komponen baru robotika (LEGO Versi 3), penyimpanan data berbasis cloud, dan visualisasi geografis (peta). Selain itu, tim App Inventor juga mengembangkan ekstensi yang terkait dengan Internet of Things (IoT) (Patton et al, 2019). Untuk mengaksesnya dapat dibuka pada url https://App Inventor.mit.edu/, kemudian lakukan pendaftaran menggunakan alamat e-mail. Setelah aktivasi, dilanjutkan dengan memulai pembuatan aplikasinya.

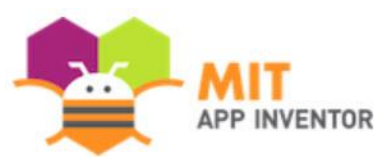

\section{Gambar 1. Logo App Inventor}




\subsection{IoT (Internet of Things)}

Menurut (Tarkoma et al, 2011) IoT adalah sebagai jaringan global yang memiliki layanan infrastruktur dan konektivitas sehingga dapat terintegrasi dengan lancar dan aman ke dalam Internet. Menurut (Weyrich., Ebert, 2019) IoT adalah tentang fungsionalitas inovatif dan produktivitas yang lebih baik dengan menghubungkan perangkat secara lancar.

\subsection{Firebase}

Pada tahun 2011, Andrew Lee dan James Tamplin mendirikan firebase dan meluncurkan basis data berbasis cloud secara realtime pada tahun 2012. Pada tahun 2014, perusahaan ini diakuisisi oleh Google. Firebase menyediakan layanan basis data secara realtime dengan layanan backend nya. Firebase memiki produk utama yang menyediakan API (Application Programming Interface) sehingga pengembang dapat membuat API untuk disinkronisasi ke client yang berbedabeda dan menyimpan pada basis data cloud nya (Sonia et al, 2018). Fitur basis data realtime ini merupakan tipe basis data NoSQL(bukan SQL) dengan struktur data JSON (Javascript Notation) (Ilhami, 2017). Untuk mengaksesnya dapat dibuka dengan url https://console.firebase.google.com/. Kemudian lakukan pendaftaran terlebih dahulu. Setelah aktivasi, dilanjutkan dengan membuat proyek baru. Lalu setelah proyek terbentuk, dapat memilih fitur realtime database.

\section{Firebase}

\section{Gambar 2. Logo Firebase}

\section{$2.4 \quad$ NodeMCU}

Merupakan gabungan dari dua kata yaitu Node dan MCU (Microcontroller Unit). NodeMCU adalah sebuah modul/perangkat keras Wi-Fi berlisensi Open Source yang terdapat firmware interaktif dengan dukungan bahasa pemrograman $L U A$. Selain dapat diprogram dengan $L U A$, dapat juga deprogram dengan bahasa $C$ melalui editor Arduino IDE (Wicaksono, 2017). Di dalam nodeMCU di dalamnya terdapat board Arduino ESP8266. Dalam memprogramnya dapat menggunakan kabel data micro USB (Satriadi et al, 2019).

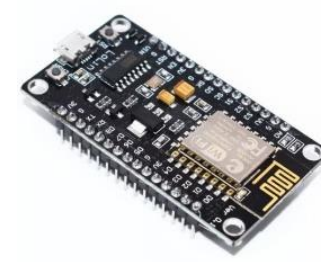

\section{Gambar 3. NodeMCU V3 Lolin}

\subsection{Pengenalan Ucapan / Speech Recognition (App Inventor Feature)}

Pada gambar dibawah ini adalah diagram proses pengenalan kata dengan teknologi Google Speech. 


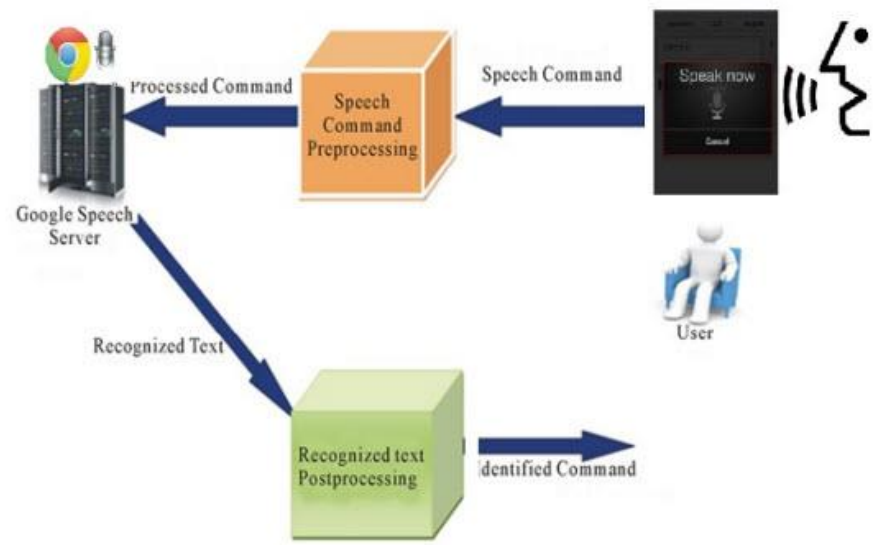

\section{Gambar 4. Diagram Proses Pengenalan Kata dengan Google Speech}

Dialog Voice input akan tampil ketika pengguna mengaktifkan fungsi Speech To Text yang telah disesuaikan dengan pilihan bahasa yang dipilih sebelumnya yaitu bahasa Indonesia. Kemudian pengguna dapat mulai berbicara melalui dialog voice input tersebut. Suara yang dihasilkan kemudian dikirim secara realtime ke server Google Speech Recognition yang nantinya akan dikonversi menjadi teks. Fungsi Google Speech Recognition adalah untuk mengkonversi suara yang diterima dan telah dibandingkan dengan database yang dimiliki Google ke dalam bentuk teks. Hasil akhirnya adalah Google Speech Recognition mengirimkan teks hasil konversi ke dalam bahasa asal yaitu bahasa Indonesia (Mohamed, 2014). Pada umumnya sinyal suara adalah hasil dari beberapa pesan yang telah dienkripsi menjadi urutan satu atau lebih simbol (Reddy, 2014).

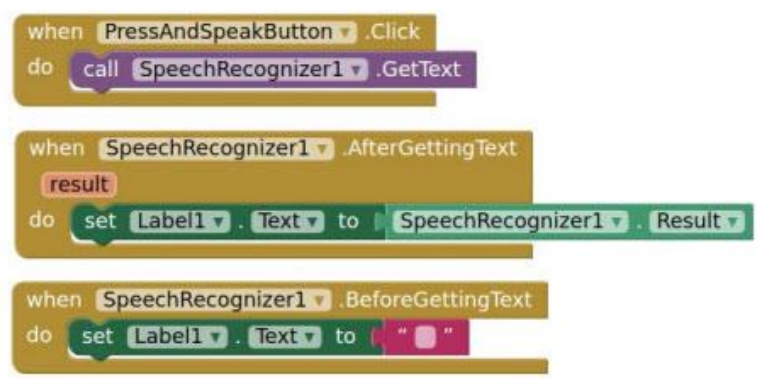

\section{Gambar 5. Blok Pemrograman Speech Recognition pada App Inventor}

\subsection{Rumah Pintar (Smart Home)}

Menurut Anbarasi (Anbarasi, 2013) smart home terbagi dalam 3 kelompok antara lain comfort, healthcare dan security. Comfort mengandung arti dapat memberikan kenyamanan kepada penghuni rumahnya. Disini terdapat dua(2) metode. Metode pertama adalah dengan adanya smart home akan dapat dengan mudah mengenali kegiatan dan intruksi penghuni dan melakukan otomatisasi terhadap peralatan listrik dirumah. Metode kedua adalah dapat dilakukan remote (pengendalian) alat-alat elektronik rumah tangga dari jauh. Healthcare artinya kehadiran smart home dapat menggantikan peran asisten rumah tangga terhadap kesehatan penghuni rumah dan dapat memberikan akses secara langsung baik ke dokter maupun rumah sakit akan data Kesehatan para penghuni rumah. Security mengandung arti bahwa teknologi smart home dapat mengatasi serangan dari pihak yang tidak berhak atau tidak diijinkan.

\subsection{Penelitian Terdahulu}

Pada tahun 2021 telah dilakukan penelitian oleh Mushlihudin dengan judul "Smart Home menggunakan Internet of Thing untuk Pengawasan Kesehatan Lansia". Penelitian ini menggunakan beberapa sensor seperti sensor gerak, suhu, kelembaban, gas, api, ultrasonic, sensor air, RFID dan sensor cahaya. Aplikasi yang dikembangkan dengan web dan smartphone menggunakan Voice Recognition (pengenalan suara). Hasil dari perintah suara ini akan 
mengendalikan berbagai perangkat eletronik rumah. Penerapannya untuk pemantauan kesehatan jarak jauh dan pemantauan lansia jatuh.

Pada tahun 2020 telah dilakukan penelitian oleh Afunia Bundha Lasera dan Ibnu Hary Wahyudi dengan judul "Pengembangan Prototipe Sistem Pengontrolan Daya Listrik berbasis IoT ESP32 pada Smart Home System". Pada penelitian ini menggunakan aplikasi Blynk dan modul ESP32 untuk mengendalikan peralatan listrik seperti lampu, kipas angin, AC, stop kontak, televisi, dan jet pump. Selain mengendalikan terdapat fungsi yang lain seperti informasi arus dan daya, informasi suhu lingkungan; dan informasi perkiraan biaya bulanan rekening listrik terkini.

Pada tahun 2019 telah dilakukan penelitian oleh Muhammad Ardi Setiawan dan Erma Susanti serta Erfanti Fatkhiyah dengan judul "Purwarupa Alat Pemantau Dan Kendali Rumah dengan Implemantasi Perangkat IoT (Internet Of Things)". Penelitian ini menggunakan modul nodeMCU dan beberapa sensor diantaranya $L D R, P I R, D H T 11$ dan $M Q 2$. Peralatan listrik yang dijadikan bahan penelitian adalah lampu rumah. Dengan menggunakan aplikasi yang terkoneksi dengan Firebase sehingga dapat menerima data sensor secara realtime dapat ditampilkan melalui aplikasi Mobile sebagai sistem informasi pemantau dan kendali dari jarak jauh serta tombol hidupkan/matikan untuk menghidupkan dan mematikan lampu rumah yang telah terpasang perangkat $I o T$.

Pada tahun 2018 telah dilakukan penelitian oleh Eko Hartono, Tony Darmanto dan Alfred Yulius Arthadi Putra dengan judul "Penerapan Speech Recognition Berbasis Smartphone Android Untuk Pengontrol Peralatan Elektronik Rumah". Penelitian ini menggunakan sensor motor $D C$, Lampu LED AC, Cooling Fan DC dan Buzzer. Penelitian ini mengembangkan aplikasi berbasis App Inventor dengan perintah Google Speech untuk memberikan input ke Arduino sehingga dapat mengendalikan peralatan listrik rumah. Speech yang dilakukan menggunakan Bluetooth.

Pada tahun 2017 telah dilakukan penelitian oleh Tesar Kurniawan, Nursin, M Amin Bakri dan Seta Samsiana dengan judul "Rancang Bangun Sistem Kendali Berbasis Google Speech Untuk Aktivasi Peralatan Listrik Rumah". Penelitian ini mengembangkan aplikasi berbasis App Inventor dengan perintah Google Speech untuk memberikan input ke Arduino sehingga dapat mengendalikan peralatan listrik rumah. Speech yang dilakukan menggunakan Bluetooth dengan diuji pada jarak 13 meter dan 20 meter.

Dari kelima penelitian yang pernah dilakukan tersebut maka peneliti mengambil beberapa teknik dan modul yang digunakan. Modul yang digunakan adalah nodeMCU. Editor aplikasi android menggunakan App Inventor. Teknik yang digunakan adalah Speech Recognition. Koneksi yang digunakan menggunakan Internet. Perangkat elektronik hanya menggunakan satu lampu. Menggunakan firebase sebagai penyimpan data secara realtime. Program dan rangkaian elektronika yang digunakan berbeda dengan kelima penelitian tersebut.

\section{METODE PENELITIAN}

\subsection{Alur Penelitian}

Penelitian ini menggunakan tahapan dimulai dari pengumpulan data, perancangan sistem, pembangunan sistem kemudian dilakukan pengujian terhadap sistem berbasis android dan IoT. Setelah proses pengujian berhasil dilanjutkan dengan implementasi sistem, jika terdapat kesalahan maka akan dilakukan perbaikan pada proses-proses sebelumnya. 


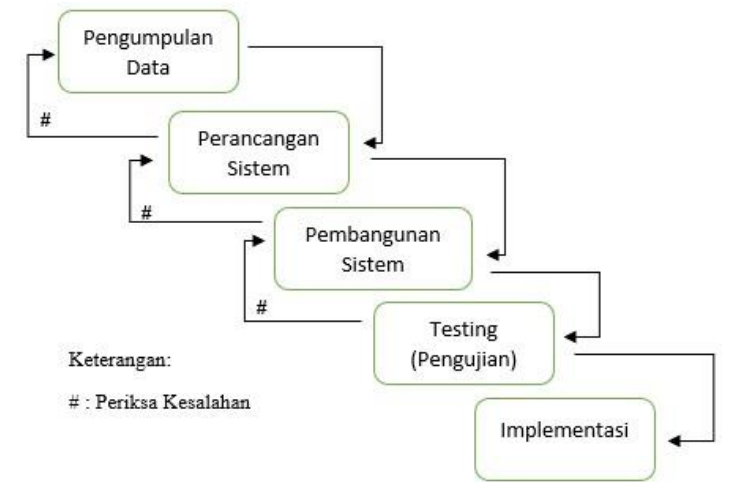

Gambar 6. Alur Penelitian

\subsection{Pengumpulan Data}

Data yang mendukung dalam penelitian ini yang diperoleh dengan membaca artikel-artikel, literatur-literatur atau buku-buku yang berhubungan dengan penelitian.

\subsection{Perancangan sistem}

Berikut adalah diagram topologi jaringan, diagram alur sistem pada aplikasi android (App Inventor) dan IoT System (perangkat keras dan program aplikasinya).

a. Topologi Jaringan

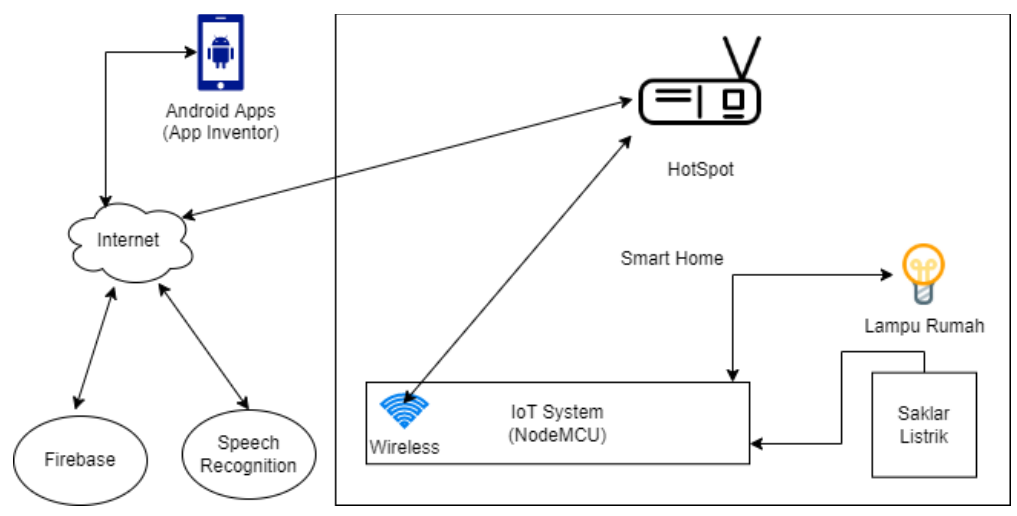

Gambar 7. Topologi Jaringan

Di dalam sistem besar yaitu smart home terdapat IoT System, peralatan listrik (lampu), saklar listrik dan perangkat hotspot yang terhubung dengan Internet. Di dalam IoT system terdapat modul nodeMCU dengan fitur Wireless (Wi-Fi). Wireless ini terhubung dengan hotspot. Program yang terdapat di nodeMCU akan mengambil data dari Firebase yang akan menentukan kondisi lampu rumah dalam keadaan hidup (on) atau mati (off).

Penghuni rumah yang kondisinya berada di luar atau jauh dari rumah dapat mengendalikan lampu rumah dengan memanfaatkan internet sebagai konektivitasnya. Dengan aplikasi yang berada di gadget/phone, penghuni rumah mengirim data baik dengan tombol maupun speech recognition ke firebase. Secara realtime juga, data itu akan diambil oleh IoT System yang terdapat di dalam smart home.

b. Diagram alur sistem pada aplikasi android (App Inventor) 


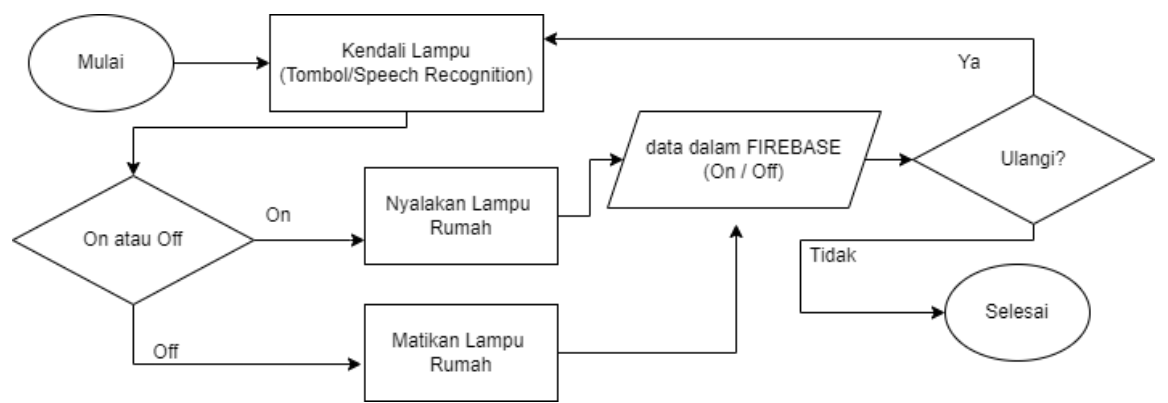

Gambar 8. Diagram Alur Program Android App Inventor

Pada program aplikasi android dengan app inventor dirancang satu tampilan untuk melakukan kendali lampu yaitu pengguna dapat menggunakan tombol atau Speech Recognition. Kemudian reaksi dari tombola atau speech recognition akan dikonversi ke dalam bentuk teks. Jika hasilnya on maka akan mengubah data di Firebase menjadi on begitu sebaliknya. Jika telah selesai, dapat menutup aplikasinya.

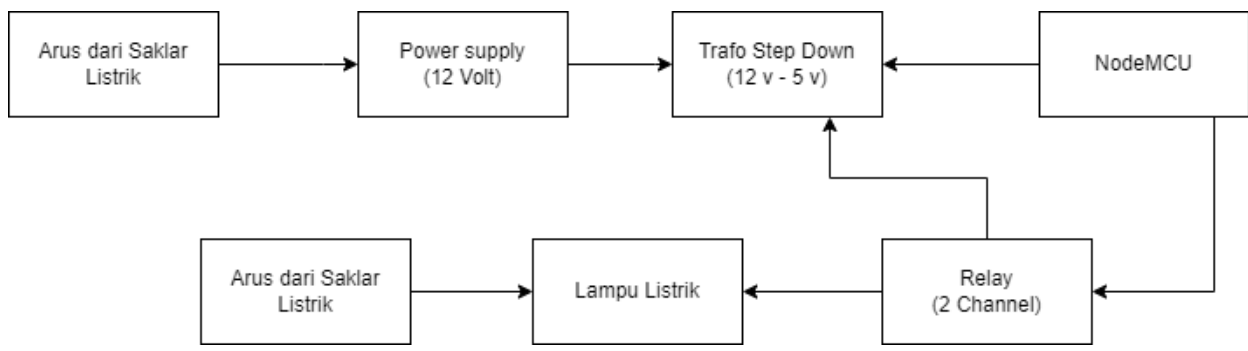

\section{Gambar 9. Alur pada perangkat keras IoT System}

Pada bagian elektronikanya tampil pada gambar 9 diatas. Rangkaian ini memerlukan 2 sumber arus listrik. Sumber arus pertama akan terhubung ke power supply. Dan sumber kedua akan terhubung ke lampu listrik rumah. Sumber arus pertama akan terhubung ke power supply lalu terhubung ke trafo step down (mengubah tegangan 12 Volt menjadi 5 Volt). NodeMCU akan terhubung ke trafo dan relay. Relay juga akan terhubung ke trafo. Relay ini diujungnya terhubung dengan lampur listrik. Lampu listrik pada bagian akhir mendapatkan arus dari sumber arus kedua. Ketika program dalam NodeMCU mengambil data dari firebase maka data tersebut akan dikonversi dalam bentuk digital signal. Digital signal pada nodeMCU akan menterjemahkan dalam bentuk aliran arus listrik sehingga dapat mengubah kondisi lampu menjadi hidup (on) atau mati (off).

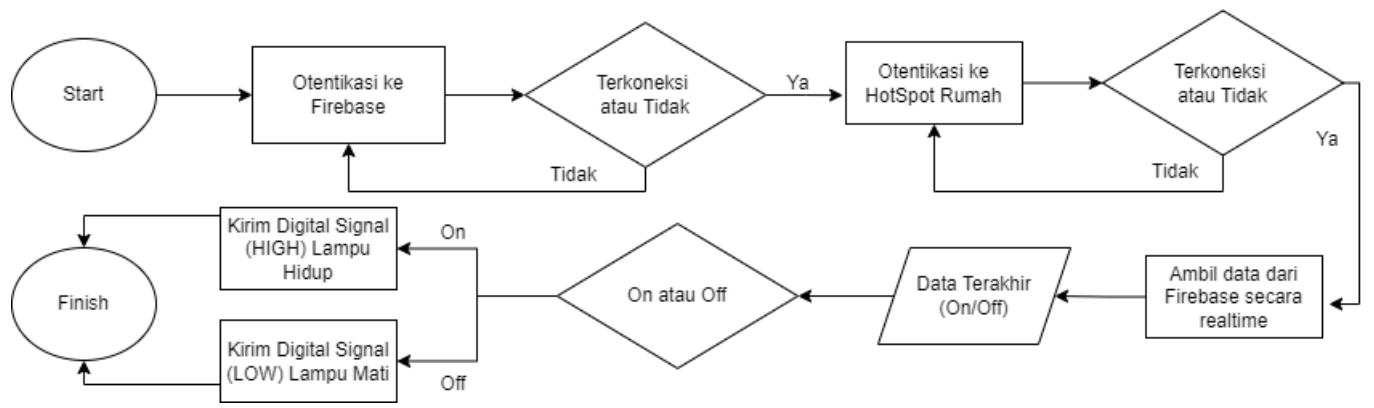

\section{Gambar 10. Alur pada Program NodeMCU}

Pada gambar 10 diatas menggambarkan alur pada program NodeMCU. Program memerlukan otentikasi terlebih dahulu ke firebase. Jika sesuai dilanjutkan dengan otentikasi ke hotspot 
(Sumber Internet secara Wireless). Jika sesuai maka program akan mengambil data terakhir dari firebase (secara realtime). Data terakhir ini akan diteruskan oleh program ke dalam bentuk sinyal digital. Jika nilainya on maka akan dikirim sinyal HIGH atau 1 (satu) sebaliknya jika nilainya off maka akan dikirim sinyal $L O W$ atau 0 (nol). Sinyal $H I G H$ akan menghidupkan lampu dan sinyal $L O W$ akan mematikan lampu.

\section{HASIL DAN PEMBAHASAN}

\subsection{Implementasi Dan Uji Perangkat Lunak}

Untuk hasil akhir dari penelitian ini adalah bentuk purwarupa yang nantinya dapat dikembangkan menjadi lebih baik lagi baik dari sisi rancangan tampilan, rangkaian elektronika maupun fungsionalitasnya. Dari perancangan yang telah dilakukan terdapat hasil akhir yaitu berupa halaman pengujian pada saat kendalikan lampu menggunakan tombol dan pada saat menggunakan speech recognition

\subsection{Tampilan Pengujian Menggunakan Tombol}

Tabel 1. Pengujian Tombol 1

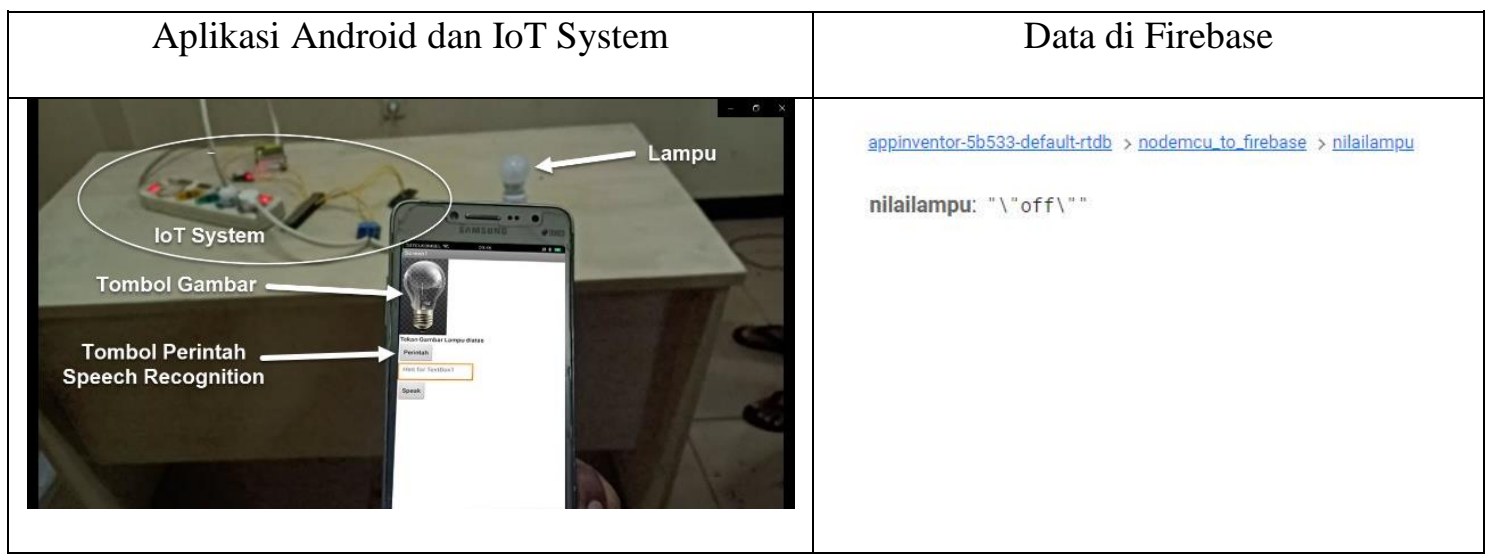

Lampu dalam kondisi mati (off). Data pada firebase menunjukkan mati (off). Untuk menyalakan lampu dapat tekan tombol bergambar, sehingga nanti gambar akan berubah menjadi gambar lampu menyala, data pada firebase akan menjadi hidup(on) dan lampu listrik akan menyala. Seperti terlihat pada tabel 2 berikut:

Tabel 2. Pengujian Tombol 2

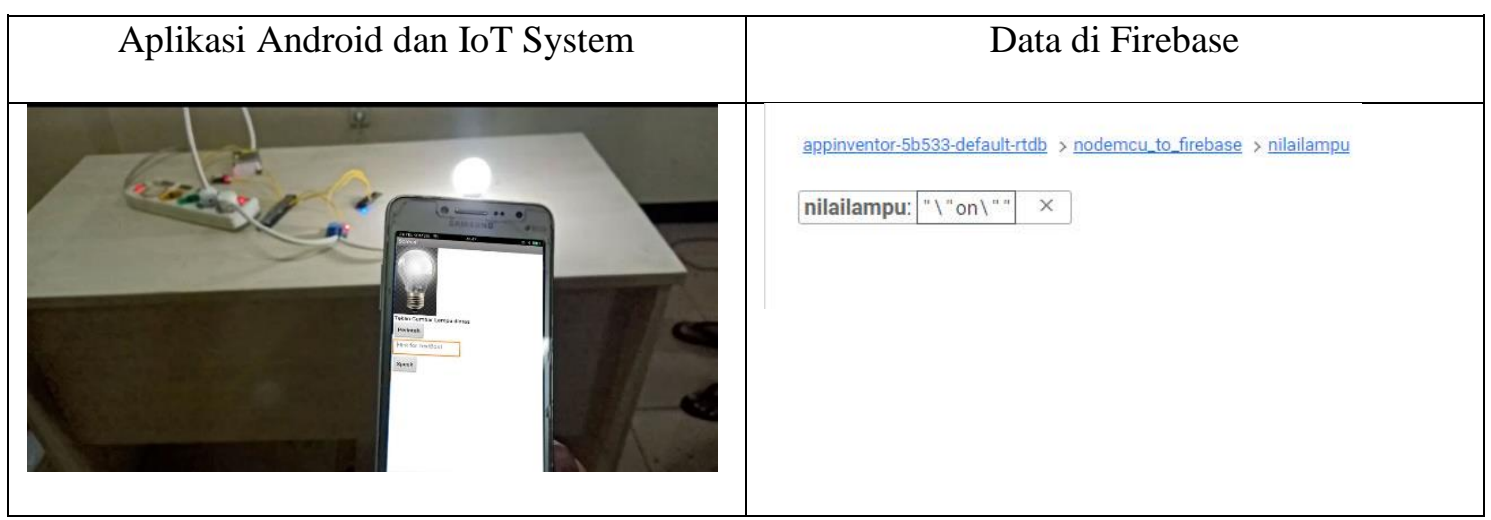

Untuk mematikan lampu, dapat menekan tombol gambar lampu yang sedang menyala. Nanti akan terlihat seperti pada tabel 1 sebelumnya. 


\subsection{Tampilan Pengujian Menggunakan Speech Recognition}

Tabel 3. Pengujian Speech Recognition 1

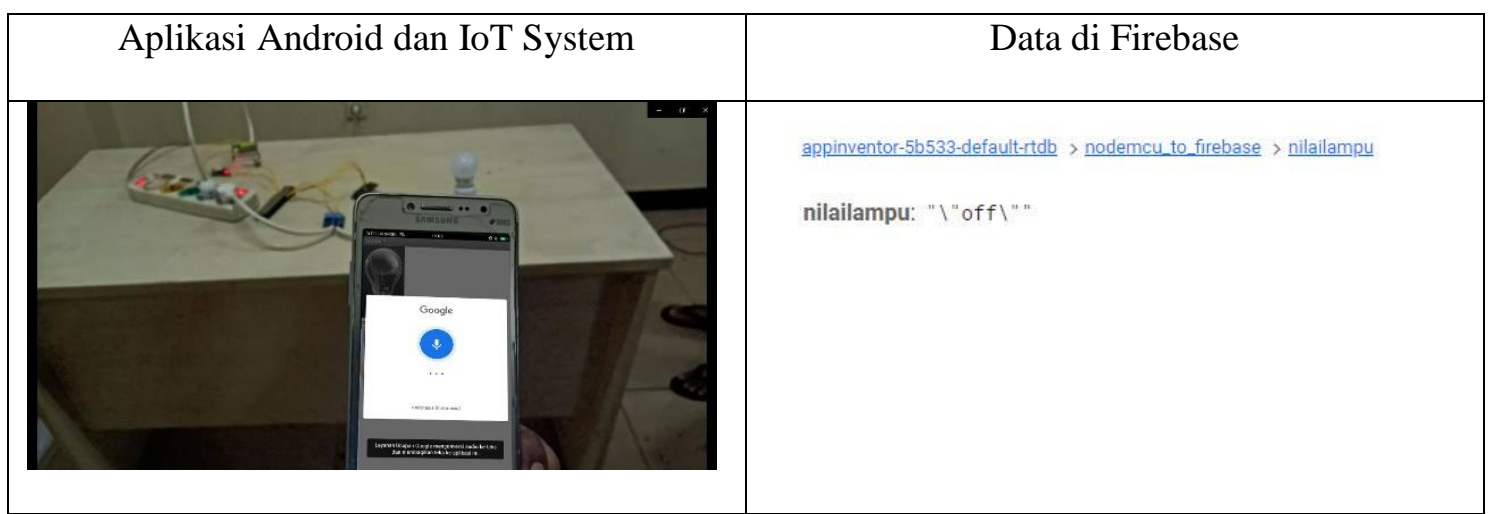

Ketika tombol perintah ditekan, makan akan muncul tampilan Google yang menandakan pengguna untuk segera mengucapkan perintah dalam bahasan Indonesia. Dalam penelitian ini untuk menyalakan lampu menggunakan perintah bahasa yaitu "cantik, nyalakan lampu". Bila dimengerti oleh program maka akan tampil seperti pada tabel 4 berikut:

Tabel 4. Pengujian Speech Recognition 2

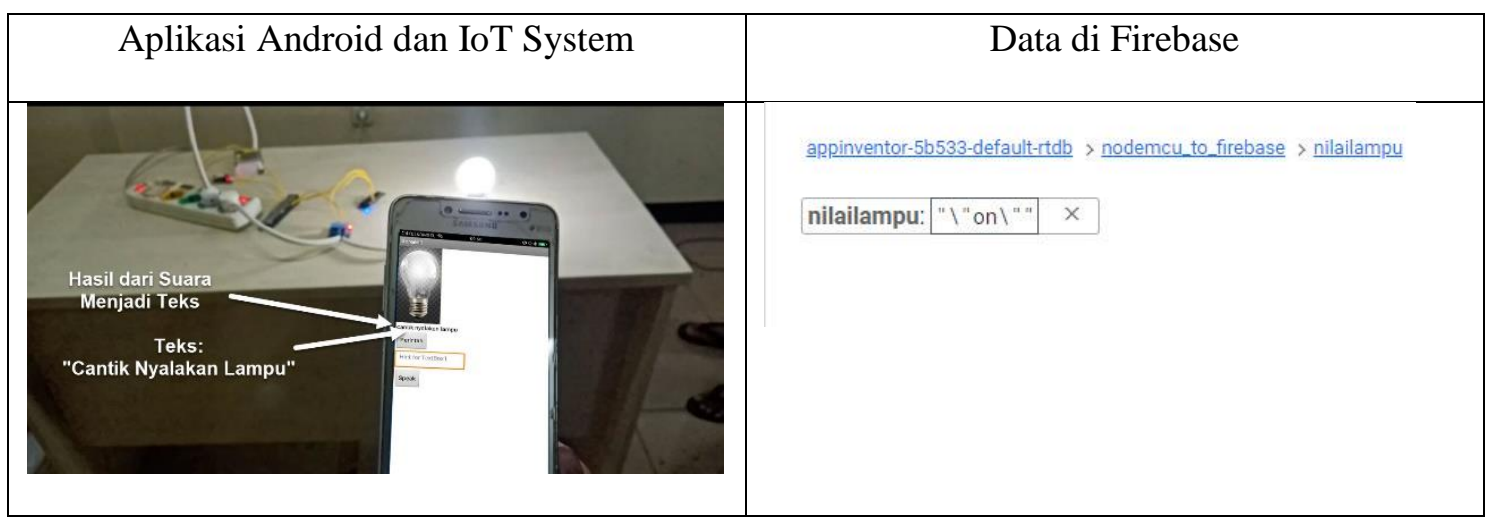

Begitupun ketika ingin mematikan lampu, tekan kembali tombol perintah, lalu muncul Google Speech, ucapkan "cantik matikan lampu". Maka lampu akan mati (off) dan data dalam firebase juga akan mati (off). Tampak pada tabel 5 berikut:

Tabel 5. Pengujian Speech Recognition 3

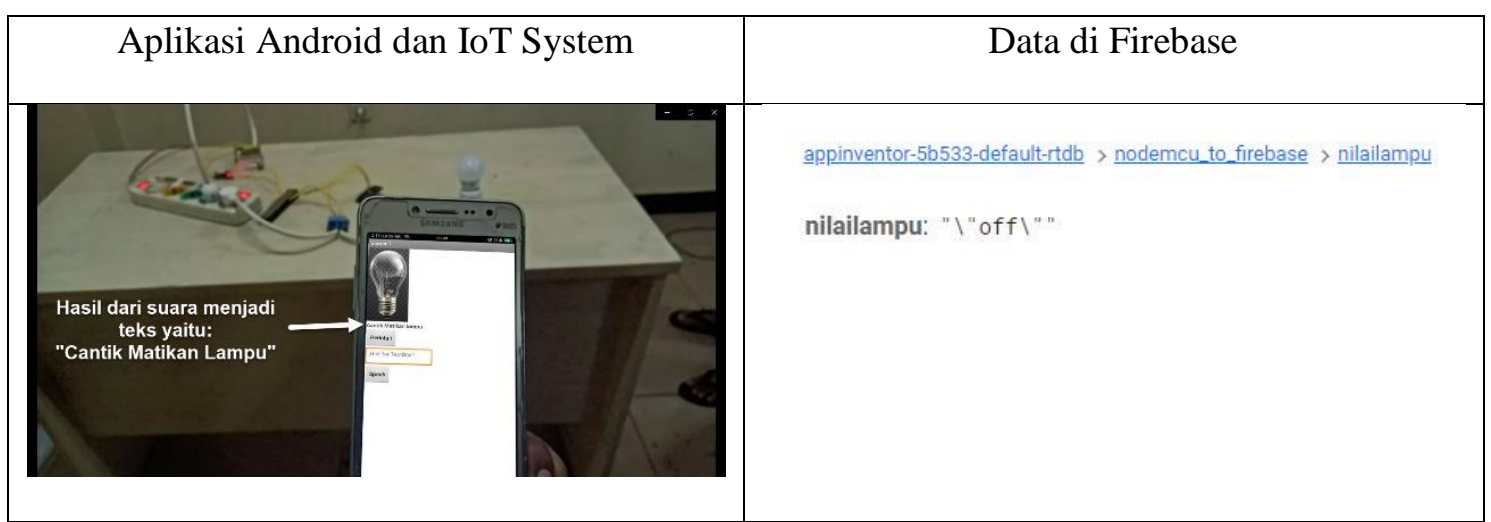

\section{KESIMPULAN DAN SARAN}

\subsection{Kesimpulan}

Pada penelitian ini mulai dari tahap perancangan sistem, pengembangan sistem, hingga tahap implementasi ditarik suatu kesimpulan sebagai berikut : 
1. Produk purwarupa aplikasi kendali lampu rumah yang berbasis IoT dan Android ini memberikan solusi pilihan selain Google smart home bagi penghuni rumah untuk menggunakan teknologi smart home dengan memanfaatkan fitur menekan tombol bergambar lampu dan tombol mengaktifkan perintah suara pada aplikasi android. Pada aplikasi android terdapat gambar lampu yang memberikan kondisi terkini lampu (menyala atau mati). Dengan mengaktifkan fitur perintah suara (Speech Recognition) pada aplikasi, pengguna dapat menggunakan kata (teks) bahasa Indonesia untuk menyalakan atau mematikan lampu. Kata atau teks yang digunakan telah ditentukan dan ditulis di dalam program.

2. Produk purwarupa ini juga dapat memberikan kemudahan bagi pengembang sistem untuk melakukan baik perubahan maupun pengembangan aplikasi android dikarenakan baik editor android maupun penyedia firebase yang berbasis website yang dapat diakses secara online dan berbasis open source. Untuk perubahan atau pengembangan program pada perangkat $I o T$ dapat menggunakan editor Arduino IDE yang dapat diunduh dan digunakan secara gratis. Khusus untuk perangkat elektronikanya tidak dapat dibongkar pasang dengan mudah dikarenakan telah direkatkan secara permanen (solder).

\subsection{Saran}

Dari aplikasi yang telah dibuat terdapat beberapa saran diantaranya adalah :

1. Purwarupa ini dapat dikembangkan untuk mengendalikan peralatan elektronik menggunakan lebih dari satu lampu. Selain itu dapat dikembangkan untuk mengendalikan peralatan elektronik lainnya dengan memanfaatkan beberapa sensor.

2. Purwarupa ini dapat dikembangkan dengan memperbaiki baik tampilan layar $(G U I)$ di sisi aplikasi android dan rangkaian elektronika yang lebih ramah pengguna.

\section{DAFTAR PUSTAKA}

Anbarasi, A.A., \& Ishwarya, M.V. (2013). Design and implementation of smart home using sensor network. 2013 International Conference on Optical Imaging Sensor and Security (ICOSS), 1-6.

Elsagheer, Mohamed., dkk. 2014.Educational System for the Holy Quran and Its Sciences for Blind and Handicapped People Based on Google Speech API. Vol.7 No.3. Journal of Software Engineering and Applications.

Hartono, Eko., Darmanto, Tony., Putra, Alfred YA. 2018. Penerapan Speech Recognition Berbasis Smartphone Android Untuk Pengontrol Peralatan Elektronik Rumah. Vol 4, No.2. Jurnal Informasi Teknologi dan Sistem (InTekSis).

Ilhami, Mirza. 2017. Pengenalan Google Firebase Untuk Hybrid Mobile Apps Berbasis Cordova. Vol 3, No.1. Jurnal IT CIDA.

Kincaid, J. 2011. Google gives Android App Inventor a new home at MIT Media Lab. Techcrunch. Retrieved March 04, 2018, from https://techcrunch.com/2011/08/16/googlegives-android-app-inventor-a-new-home-at-mit-media-lab/.

Kurniawan, Tesar., Nursin., Bakri, M Amin., Samsiana Seta. 2017. Rancang Bangun Sistem Kendali Berbasis Google Speech Untuk Aktivasi Peralatan Listrik Rumah. Vol 5, No.2. Journal of Electrical and Electronics.

Lasera, A.B., \& Wahyudi, I.H. 2020. Pengembangan Prototipe Sistem Pengontrolan Daya Listrik berbasis IoT ESP32 pada Smart Home System. ELINVO (Electronics, Informatics, and Vocational Education). Vol.5, No.2, 112-120. https://doi.org/10.21831/elinvo.v5i2.34261.

Lynn T., Endo P.T., Ribeiro A.M.N.C., Barbosa G.B.N., Rosati P. 2020. The Internet of Things: Definitions, Key Concepts, and Reference Architectures. In: Lynn T., Mooney J., Lee B., Endo P. (eds) The Cloud-to-Thing Continuum. Palgrave Studies in Digital Business \& Enabling Technologies. Palgrave Macmillan, Cham. https://doi.org/10.1007/978-3-03041110-7_1.

Mushlihudin. 2021. Smart Home menggunakan Internet of Thing untuk Pengawasan Kesehatan Lansia. Vol.5 No.2. Jurnal Nasional Informatika dan Teknologi Jaringan. 
Patton E.W., Tissenbaum M., Harunani F. 2019. MIT App Inventor: Objectives, Design, and Development. In: Kong SC., Abelson H. (eds) Computational Thinking Education. Springer, Singapore. https://doi.org/10.1007/978-981-13-6528-7_3.

Reddy, R. B., \& Mahender, E. (2013). Speech To Text Conversion Using Android Platform. International Journal of Engineering Research and Applicaiton (IJERA). Vol. 3, No.1, 253-258.

Satriadi, A., Wahyudi, W., \& Christyono, Y. 2019. PERANCANGAN HOME AUTOMATION BERBASIS NodeMCU. Transient: Jurnal Ilmiah Teknik Elektro, 8(1), 64-71. https://doi.org/10.14710/transient.8.1.64-71.

Setiawan, M.A., Susanti, E., \& Fatkhiyah, E. 2019. Purwarupa Alat Pemantau Dan Kendali Rumah Dengan Implemantasi Perangkat IoT (Internet Of Things). Jurnal SCRIPT, Vol.7, No.1, 61-69.

Tarkoma, Sasu, and Artem Katasonov. 2011. Internet of Things Strategic Research Agenda (IoTSRA). Finnish Strategic Centre for Science, Technology, and Innovation: For Information and Communications (ICT) Services, Businesses, and Technologies, Finland.

Sonita, Anisha., Fardianitama, Rizki Fitriah. 2018. Aplikasi E-Order Menggunakan Firebase dan Algoritma Knuth Morris Pratt Berbasis Android. Jurnal Pseudocode. Vol. V, No. 2.

Weyrich, Michael, and Christof Ebert. 2016. Reference Architectures for the Internet of Things. IEEE Software 33, no. 1: 112-116. Accessed December 2019. https://doi.org/10.1109/MS.2016.20.

Wicaksono, M. 2017. Implementasi Modul Wifi Nodemcu Esp8266 Untuk Smart Home. Komputika : Jurnal Sistem Komputer. 6, 1 (Sep. 2017). 